\title{
Turkish Validity and Reliability Study of the Leisure Constraint Questionnaire
}

\author{
Mehmet Ali ÖZTÜRK ${ }^{1}$, Ahmet YIKILMAZ ${ }^{2}$ \& Eyyüp SARIKOL ${ }^{2}$ \\ ${ }^{1}$ School of Physical Education and Sports, Karabük University, Karabük, Turkey \\ ${ }^{2}$ School of Physical Education and Sports, Iğdır University, Iğdır, Turkey \\ Correspondence: Mehmet Ali Öztürk, School of Physical Education and Sports, Karabük University, Karabük, \\ Turkey. E-mail: mali.ozturk@karabuk.edu.tr
}

\author{
Received: October 23, $2018 \quad$ Accepted: November 19, $2018 \quad$ Online Published: December 30, 2018 \\ doi:10.5539/jel.v8n1p150 URL: https://doi.org/10.5539/jel.v8n1p150
}

\begin{abstract}
The purpose of this study to adapt to Turkish version by applying validity and reliability test of Leisure Constraint Questionnaire (LCQ) developed by Alexander and Carroll (1997). 214 (62.4\%) men and 129 (37.6\%) women, total of 343 people was participated to the study working as public officers in Iğdır. Exploratory Factor Analysis (EFA), Reliability Analysis and Confirmatory Factor Analysis (CFA) was applied to Turkish version of the scale after translated to Turkish. When the EFA results are examined Anti Imaj Correlation (AIC) cross correlation coefficients of all items greater than 0.5 and It has been decided to use all items in the analysis. After Principal Component Analaysis (PCA), there are 7 factors with eigenvalue greater than 1 and the contribution of these factors to the total variance is $56.806 \%$ were determined. The factors belonging to the items were determined by Rotated Component Matrix (VARIMAX). The tests of Cronbach's Alpha (CA), Spearman-Brown Correlation (SBC) and Guttman Split Half Correlation (GSHC) were performed for reliability of the scale. The value of CA: 0.876, SBC: 0.754 and GSHC: 0.754 were found for the all items. Comparative Fit Index (CFI), Goodness-of-fit index (GFI) and he Normed Fit Index (NFI) were used for the CFA. As a result of CFA analysis; the value of CFI: 0.94, GFI: 0.96 and NFI: 0.93 were found. It has been concluded that the scale of adaptation to Turkish is valid and reliable and also it was composed of 7 factors and 29 items like original scale.
\end{abstract}

Keywords: leisure time, constraint, validity, reliability

\section{Introduction}

Although there is no universal definition of leisure time; leisure time is typically described as free time as a time period for activities to get pleasure (Kindal et al., 2010). According to many scientists, leisure time; the various activities that we want, or suggested to us, are defined as the time we perform in accordance with our wishes and in return for a financial gain (Sindık \& Puljic, 2010). In other words, leisure time is a time when the person will be free of all difficulties or relations for himself and others and will take an action of his own will (Güngörmüş et al., 2006). Therefore, the free time includes the non working time period (İlhan \& Balc1, 2006).

The first thing that comes to mind when participating in leisure activities is that they are in a time frame. First of all, it is necessary to talk about a free time outside of the work that is performed or routine. According to T. Veblen, the term 'leisure time with his work The Theory of the Leisure Class 'published in 1899; expresses neither laziness nor rest. For him, free time is the consumption of time without production. In order to eliminate the complexity of the definition; food, sleep and sexual needs, such as physiological, family and business life, except for the occupational activities, depending on the individual's preference alone or as a group can be defined as the time devoted to activities performed freely (Aslantürk \& Amman, 2009).

For many years, the focus of studies on leisure time has been more related to leisure time constraints (Samdahl \& Jekubovich, 1997). Empirical studies, especially after the millennium, have been presented on the whole population, such as adult individuals, women and people with disabilities (Casper et al., 2011). One of the most frequently cited articles has tested multivariate models of analysis, including relationships between constraints, negotiation, motivation and participation (Hubbard \& Mannell, 2001). Never the less, cross cultural college students have been studied extensively with varying degrees of differences (Guo \& Schneider, 2015). Confirmatory factor analysis is a widely used method in which participants' perceptions are highly dependent 
and each may have different scaling standards (Ting-Wen \& Chung-Tai, 2016).

Factors affecting leisure activities started to be examined in the 1950s (Reeder \& Linkowski, 1976; Witt \& Goodale, 1981). In the first studies on leisure time, participation barriers were more involved (Searle ve Jackson, 1985). In the process, not only the reasons that barriers physical activity, but also the reasons that make it difficult have attracted the attention of academics and the researchers started to use these two dimensions under the name of an "constraints"(Crawford \& Godbey, 1987; Crawford \& Huston, 1993). For this reason, instead of the word of barriers today, the word of constraints has become a preferred concept (Crawford et al., 1991; Jackson, 1990). Studies examining factors that constraints leisure activities have increased significantly in the 1980s (Jackson, 1991). In these studies; In time activities, changing trends have been examined and people and societies are classified according to their tendency to choose leisure activities (Jackson \& Witt, 1994).

Leisure constraints are commonly defined as factors which affect individuals' formation of leisure preferences for particular activities and limit their ability to participate in the activities (Jackson \& Scott, 1999). Crawford and Godbey (1987), in the model they developed, the factors that restrict participation in leisure time activities are grouped into three main groups: structural, interpersonal and intrapersonal. Structural constraints which are the most important and most studied constraints (Jackson, 2005), generally refer to physical constraints, geographical conditions such as bad weather, financial difficulties and time constraints (Walker \& Virden, 2005).

Raymore et al. (1993) presented a comprehensive measure of leisure constraints based on the literatures (Crawford \& Godbey, 1987; Crawford et al., 1991). Each of the constraints is consisted of seven aspects. Intrapersonal constraints include: religion, self-conscious, shy, skill, uncomfortable, alright with family, and alright with family. Interpersonal constraints include: others' know activities, others' money, others' obligations, others' skills, others' time, others' transport, and others too far. Structural constraints include convenient, know what's available, money, not crowded, other.

Studies on this field in our country are limited. In order to contribute to the current literature, the aim of this study was to evaluate the Turkish validity and reliability of the "Leisure Constraints Scale" which was developed by Alexandris and Carroll (1997) and used in many studies.

\section{Method}

\subsection{Model of Research}

The aim of this study is to test the validity and reliability of the Leisure Contstraint Questionnaire (LCQ) developed by Alexandris and Carroll (1997). The descriptive survey model was used in the research. The descriptive survey model is known as a research approach that aims to describe a situation that has existed in the past or is still present. In this model, the individual, subject, event, subject to the study is tried to be defined in its own conditions and as it is (Karasar, 2000). The Turkish adaptation study of the LCQ which was applied in order to determine the participants' restrictions on recreational sportive activities, was performed using Explanatory Factor Analysis (EFA) and Confirmatory Factor Analysis (CFA).

\subsection{Sampling}

The aim of this study is to test the validity and reliability of the Leisure Contstraint Questionnaire (LCQ) developed by Alexandris and Carroll (1997). The descriptive survey model was used in the research. The descriptive survey model is known as a research approach that aims to describe a situation that has existed in the past or is still present. In this model, the individual, subject, event, subject to the study is tried to be defined in its own conditions and as it is (Karasar, 2000). The Turkish adaptation study of the LCQ which was applied in order to determine the participants' restrictions on recreational sportive activities, was performed using Explanatory Factor Analysis (EFA) and Confirmatory Factor Analysis (CFA).

\subsection{Data Collection Tool}

The original of the scale (Leisure Constraints Questionnaire) was developed by Alexandris and Carroll (1997) by applying 153 people in Larissa, Greece. After the factor analysis, it was determined that the scale was composed of 7 sub-dimensions (factors) given below and the contribution of these factors to the total variance was $61 \%$. Distribution of the items in the scale to factors:

- Psychological: 7 items including psychological and personal constraints.

- Knowledge: 4 items that participants are not aware of opportunities.

- Facilities: 5 items associated with the facility and service. 
- Accessibility: 4 items relating to financial and access.

- Interest: 3 items related to the lack of interest or lack of interest from past experiences.

- Partners: 3 items related to the absence of persons / persons to participate in the activities together.

- $\quad$ Time: 3 items associated with the time problem.

As a result of the internal consistency analysis applied to the scale, Cronbach's Alpha coefficient for all of the scale and for each sub-dimension was between 0.59 and 0.81 and the scale was accepted as reliable for usability in research (Alexandris ve Carroll, 1997).

\subsection{Analysis of Data}

The translation of the scale into Turkish by a language expert, and then, by another language expert, the Turkish materials were translated into English and the questions were adapted to the original scale. With KMO and Bartlett tests, it was checked whether the scale was suitable for factor analysis. After determining the feasibility of factor analysis, Explanatory Factor Analysis (EFA), Reliability Analysis and Confirmatory Factor Analysis (CFA) were applied to the scale. According to EFA results; After Anti Image Correlation (AIC), the cross-correlation coefficients of all items were found to be greater than 0.5 and it was decided not to remove any items from the analysis. After Principal Component Analysis (PCA), 7 factors (psychological, knowledge, interest, partners, accessibility, facilities and time) with eigenvalues greater than 1 were found and the contribution of these factors to total variance was found to be $56,806 \%$. The items belonging to these factors were determined by VARIMAX technique of Rotated Component Matrix (RCM). Cronbach's Alpha (CA), Spearman-Brown Correlation (SBC) and Guttman Split Half Correlation (GSHC) tests were performed to determine the reliability of the scale and found to be CA: 0.876 , SBC: 0.754 and GSHC: 0.754 . In addition, the $\mathrm{CA}$ test was performed for 7 factors of the scale and the $\mathrm{CA}$ value for the sub-dimensions was determined as psychological: 0.712 , knowledge: 0.734 , interest: 0.721 , partners: 0.716 , accessibility: 0.771 , facilities: 0.740 and time: 0.726 .

The CFA chi-square / degree of freedom $(\chi 2)$ ratio was performed using the Comparative Fit Index (CFI), the Goodness of Fit Index (GFI) and the Normed Fit Index (NFI) analyzes. As a result of CFA analysis, CFI: 0.94, GFI: 0.96 , NFI: 0.93 were determined. One of the most important model fit indices in CFA is the $\chi^{2}$ value. $\chi 2$ The goodness of fit gives a measure of how far the observed correlation matrix is away from the theoretical correlation matrix. One of the criteria that the model and the data fit well is that the $\chi 2$ value is low. In evaluating the fit indices; CFI of 0.97 and above good, acceptable level between 0.95 and 0.97 , GFI and NFI 0.95 and above good, 0.90-0.95 between the acceptable level is expressed as.

As a result of the analysis; It was concluded that the scale adapted to Turkish was valid and reliable and consisted of 7 factors and 29 items, as in the original scale.

\section{Results}

Table 1. KMO and Bartlett test of sphericity results

\begin{tabular}{lll}
\hline Kaiser- Meyer- Olkin Sampling Proficiency Measurement & 0.824 \\
\hline \multirow{3}{*}{ Bartlett Test of Sphericity } & chi-square & 2599.002 \\
& df & 406 \\
& P & 000 \\
\hline
\end{tabular}

Table 2. Cronbach alpha, spearman brown and split half correlations (all scale) and cronbach alpha test (sub-dimensions)

\begin{tabular}{llll}
\hline Factors (Sub-Dimensions) & Cronbach's Alpha & Spearman-Brown & Guttman Split Half \\
\hline Psychological & 0.712 & & \\
Knowledge & 0.734 & & \\
Facilities & 0.740 & & \\
Accessibility & 0.771 & & \\
Interest & 0.721 & & \\
Partners & 0.716 & & \\
Time & 0.726 & 0.754 & 0.754 \\
All Scale & 0.876 & & \\
\hline
\end{tabular}


The suitability of sample size for factor analysis was measured by KMO and Barlett's Sphericity test in Table 1 . When Table 1 is examined, KMO value was determined as 0,824 and data were found to be suitable for factor analysis. The value of Bartlett Sphericity was found to be $p<0.000$, which showed that the data came from a multivariate normal distribution.

Table 3. Anti image correlation matrix, rotated component matrix and total variance explanations of factors

\begin{tabular}{|c|c|c|c|c|c|c|c|c|}
\hline Item* & psychological & knowledge & facilities & accessibility & interest & partners & Time & AICM** \\
\hline It makes me feel tired & .750 & & & & & & & .789 \\
\hline Afraid of getting hurt & .743 & & & & & & & .784 \\
\hline Not happy in social situation & .721 & & & & & & & .852 \\
\hline Feel too tired for recreation & .667 & & & & & & & .832 \\
\hline Health-related problems & .636 & & & & & & & .852 \\
\hline Not confident & .595 & & & & & & & .661 \\
\hline Not fit enough & .585 & & & & & & & .730 \\
\hline Not know where to participate & & .791 & & & & & & .822 \\
\hline Not have anyone to teach me & & .660 & & & & & & .854 \\
\hline Not know where I can learn it & & .548 & & & & & & .822 \\
\hline Not skilled enough & & .458 & & & & & & .816 \\
\hline Facilities poorly kept & & & .780 & & & & & .745 \\
\hline Facilities crowded & & & .694 & & & & & .843 \\
\hline Facilities inadequate & & & .656 & & & & & .794 \\
\hline Do not like activities offered & & & .580 & & & & & .875 \\
\hline $\begin{array}{l}\text { Timetable does not fit with } \\
\text { mine }\end{array}$ & & & .516 & & & & & .873 \\
\hline $\begin{array}{l}\text { Transportation takes too much } \\
\text { time }\end{array}$ & & & & .818 & & & & .874 \\
\hline No opportunity near my home & & & & .753 & & & & .850 \\
\hline No car & & & & .709 & & & & .752 \\
\hline Cannot afford & & & & .680 & & & & .864 \\
\hline Not enjoyed in the past & & & & & .798 & & & .863 \\
\hline Not want to interrupt routine & & & & & .666 & & & .877 \\
\hline Not interested & & & & & .537 & & & .847 \\
\hline Friends do not have time & & & & & & .709 & & .856 \\
\hline Nobody to participate with & & & & & & .630 & & .866 \\
\hline $\begin{array}{l}\text { Friends do not like } \\
\text { participating }\end{array}$ & & & & & & .424 & & .809 \\
\hline Time: family & & & & & & & .746 & .805 \\
\hline Time: work/studies & & & & & & & .670 & .790 \\
\hline Time: social commitments & & & & & & & .506 & .765 \\
\hline Eigenvalue & 6.61 & 2.66 & 2.09 & 1.52 & 1.29 & 1.18 & 1.09 & \\
\hline$\%$ of variance explained & 22.82 & 9.20 & 7.21 & 5.25 & 4.45 & 4.093 & 3.77 & \\
\hline Cumulative $\%$ of variance & 56.806 & & & & & & & \\
\hline
\end{tabular}

As a result of the reliability analysis performed for the whole scale, Cronbach's Alpha was found to be 0.876 , Spearman-Brown Correlation 0.754 and Guttman Split Half Correlation 0.754. In addition, Cronbach's Alpha values for psychological, knowledge, facilities, accessibility, interest, partners and time sub-dimensions were found as $0.712,0.734,0.740,0.771,0.721,0.716,0.726$, respectively.

According to the results of the Anti-Image Correlation Matrix (AICM), where the cross-linking of the items with them was observed, the values of all substances were found to be greater than 0.5 (Table 1). This result indicates that all items can be included in factor analysis. As a result of factor analysis, 7 factors with eigenvalues greater than 1 were found. In Table 1, the rotated component matrix analysis reveals which substance belongs to which factor. According to this, the distribution of the number of items to sub-dimensions: psychological (7 items), knowledge (4 items), facilities ( 5 items), accessibility (4 items), interest ( 3 items), partners ( 3 items) and time (3 items). The contribution of these items to total variance was found to be $56,806 \%$ (Table 1 ).

The structural equation model of CFA performed after EFA is given in Figure 1. According to the results of the fit index analysis of the model; CFI: 0.94, GFI: 0.96 and NFI as 0.93 (Table 4). 


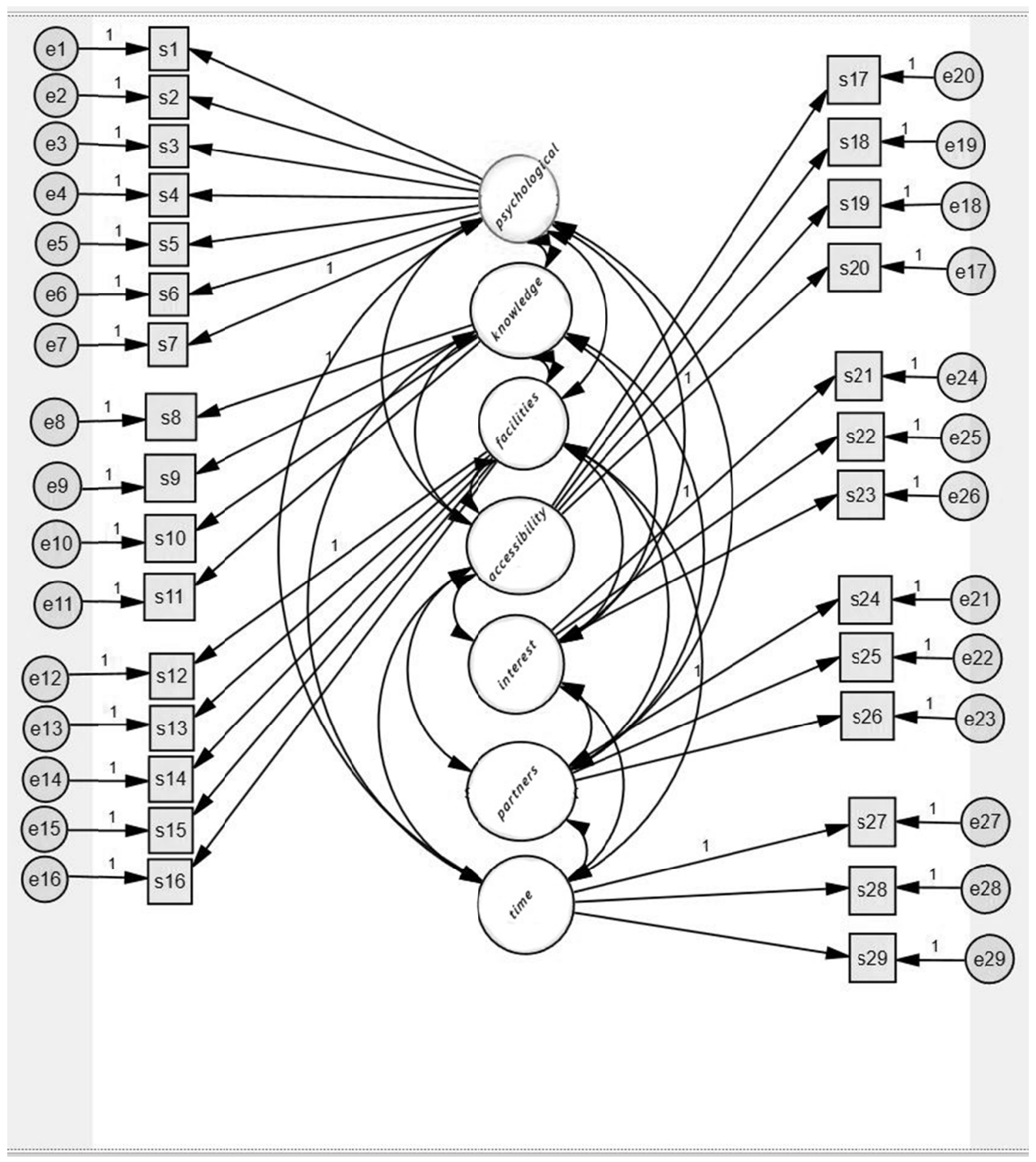

Figure 1. 7-factor CFA results

Table 4. CFA Compliance İndex Results

\begin{tabular}{llll}
\hline Fit Criteria & Good Fit & Acceptable Fit & CFA RESULTS \\
\hline CFI & $0.97 \leq \mathrm{CFI} \leq 1.00$ & $0.95 \leq \mathrm{CFI}<0.97$ & 0.94 \\
GFI & $0.95 \leq \mathrm{GFI} \leq 1.00$ & $0.90 \leq \mathrm{GFI}<0.95$ & 0.96 \\
NFI & $0.95 \leq \mathrm{NFI} \leq 1.00$ & $0.90 \leq \mathrm{NFI}<0.95$ & 0.93 \\
\hline
\end{tabular}

\section{Discussion}

Validity is a measure of what is to be measured. The most preferred content / scope validity in evaluating the validity of a scale is its validity and construct validity (Karasar, 2000). The fact that the experts agree on the comprehensibility and appropriateness of the substances is considered as an indicator for the content validity of 
the scale (Gözüm \& Aksayan, 2002).

Item analysis refers to the relationship between the value of each item in the measurement instrument and the total value of the measurement instrument. It is used in the selection of the items that determines the extent to which the measuring instrument is completely related to the measuring instrument. For this, the correlation coefficient is evaluated (Tezbaşaran, 1997; Özdamar, 2002).

It can be decided that test items with low correlation coefficients are not sufficiently reliable and that item can be omitted from the scale (Karasar 2000). The high correlation coefficient obtained for each item indicates that the substance has a high correlation with the measured theoretical structure, and that the substance is effective and sufficient to measure the intended behavior. It is recommended that the acceptable coefficient should be greater than 0.25 and the items with low correlation should be removed from the measuring instrument regardless of the other analysis results (Öner, 1997; Tezbaşaran, 1997; Özdamar, 2002).

Although some studies have been carried out especially in our country about leisure constraints (Gümüş et al., 2014; Tütüncü et al., 2011), increasing the studies related to the subject will make important contributions to the literatureIn this context, this study was carried out in order to realize the Turkish adaptation of Leisure Constraint Questionnaire, which was developed by Alexander and Carroll (1997), in order to make the Turkish source shortage possible in order to contribute to the researchers.

In order to determine the construct validity of the scale, which was translated into Turkish, exploratory and confirmatory factor analysis was used. Factor analysis was performed to determine the structural validity of the scale, to determine the factor loads of the items in the scale and to determine which subdimension should be included.

The suitability of the sample size for factor analysis was measured by Kaiser Meyer Olkin (KMO) and Bartlett Sphericity Test. The KMO value is a measure of whether the data are suitable for factor extraction. In order for the data to be suitable for factor analysis, the KMO value should be above 0.60. Bartlett's Globality test examines the relationship between variables on the basis of partial correlations. Calculated $\chi^{2}$ statistics are considered to be an indication that the data matrix is appropriate (Büyüköztürk, 2008). In our study, KMO value was determined as 0.824 . Barlett Globality value $(\chi 2=2599.002, \mathrm{p}<0.000)$ was found. Both results indicate that the data are suitable for factor analysis.

In order to exclude from the analysis, the cross-correlation of the substances with them was measured by the Anti-Image Correlation Matrix (AICM). According to the AICM analysis, it was seen that the values of all items were greater than 0.5 . This result indicates that all items can be included in factor analysis. As a result of factor analysis, 7 factors (sub-dimension) with eigenvalue greater than 1 were found. Rotated Component Matrix Analysis was applied to collect information about the construct validity of the scale. This analysis reveals which item belongs to which factor. According to this, the distribution of the number of items to sub-dimensions: psychological (7 items), knowledge (4 items), facilities (5 items), accessibility (4 items), interest (3 items), partners ( 3 items) and time ( 3 items) It took place. The contribution of these substances to total variance was found to be $56.806 \%$. This variance is acceptable for a 7 -factor scale.

According to the results of the CFA fit index analysis (Table 4), CFI: 0.94, GFI: 0.96 and NFI was 0.93 . These results indicate that substances have good and acceptable fit index.

Internal consistency levels were measured by Cronbach's Alpha, Spearman-Brown Correlation and Guttman Split Half Correlation. According to this; Cronbach's Alpha was found to be 0.876, Spearman-Brown Correlation 0.754 and Guttman Split Half Correlation 0.754. As a result of the reliability analysis test applied to 7 factors; Psychological, knowledge, facilities, accessibility, interest, partners and time Cronbach's Alpha values were found to be $0.712,0.734,0.740,0.771,0.721,0.716,0.726$, respectively.

In our study, it was aimed to adapt "Leisure Constraints Questionnaire" developed by Alexandris and Carroll (1997) to Turkish. As a result of the analyzes, a validated scale of Turkish version of 7 items (psychological, knowledge, facilities, accessibility, interest, partners and time) was developed.

\section{References}

Alexandris, K., \& Carroll, B. (1997). An analysis of leisure constraints based on different recreational sport participation levels: Results from a study in Greece. Leisure Sciences, 19(1), 1-15. https://doi.org/10.1080/01490409709512236

Aslantürk, Z., \& Amman, M. T. (2009). Sosyoloji: Kavramlar, kurumlar süreçler, teoriler (6.Baskı). İstanbul: Çamlıca Yayınları. 
Büyüköztürk, Ş. (2008). Sosyal bilimler için veri analizi el kitabl. Ankara: Pegem Akademi.

Casper, J. M., Bocarro, J. N., Kanters, M. A., \& Floyd, M. F. (2011). Measurement properties of constraints to sport participation: A psychometric examination with adolescents. Leisure Sciences, 33, 127-146. https://doi.org/10.1080/01490400.2011.550221

Crawford, D. W., \& Godbey, G. (1987). Reconceptualizing barriers to family leisure. Leisure Sciences, 9, 119-127. https://doi.org/10.1080/01490408709512151

Crawford, D. W., Jackson, E. L., \& Godbey, G. (1991). A hierarchical model of leisure constraints. Leisure Sciences, 13(4), 309-320. https://doi.org/10.1080/01490409109513147

Crawford, D., \& Huston, T. (1993). The impact of the transition to parenthood on marital leisure. Personality and Social Psychology Bulletin, 19, 39-46. https://doi.org/10.1177/0146167293191005

Gözüm, S., \& Aksayan, S. (2002). Kültürlerarası ölçek uyarlaması için rehber II: Psikometrik özellikler ve kültürlerarası karsılastırma. Hemsirelikte Arastırma Gelistirme Dergisi, 4(2), 9-20.

Gümüş, H., Işık Ö., Karakullukçu, Ö., \& Yıldırım, İ. (2014). Ortaöğretim Kurumlarında Serbest Zaman Fiziksel Aktivite Kisitlayıc1lar1. International Journal of Science Culture and Sport, 2(1), 814-825. https://doi.org/10.14486/JJSCS152

Güngörmüş, H. A., Yetim, A. A., \& Çalık, C. (2006). Ankara'daki Beden Eğitimi ve Spor Öğrenimi Veren Yüksek Öğretim Kurumlarında Görev Yapan Öğretim Elemanlarının Boş Zamanlarını Değerlendirme Biçimlerinin Araştırılması. Kastamonu Ĕ̈itim Dergisi, 14(2), 665-678.

Guo, T., \& Schneider, I. (2015). Measurement properties and crosscultural equivalence of negotiation with outdoor recreation constraints. Journal of Leisure Research, 47(1), 125-153. https://doi.org/10.1080/00222216.2015.11950354

Hubbard, J., \& Mannell, R. C. (2001). Testing competing models of the leisure constraint negotiation process in a corporate employee recreation setting. Leisure Sciences, 23(3), 145-163. https://doi.org/10.1080/014904001316896846

İlhan, A., \& Balcı, V. (2006). Türkiye' deki Üniversite Öğrencilerinin Rekreatif Etkinliklere Katılım Düzeylerinin Belirlenmesi. Spormetre Beden Eğitimi ve Spor Bilimleri Dergisi, 4(1), 11-18.

Jackson, E. L. (1990). Trends in leisure preference: Alternative constraints-related explanations. Journal of Applied Recreation Research, 15, 129-145.

Jackson, E. L. (1991). Research update: Leisure constraints. Parks and Recreation, 73, 18-23.

Jackson, E. L. (2005). Constraints to Leisure. State College, PA: Venture.

Jackson, E. L., \& Scott, D. (1999). Constraints to leisure. In E. L. Jackson \& T. L. Burton (Eds.), Leisure studies: Prospects for the twenty-first century (pp. 299-321). State College, PA: Venture.

Jackson, E. L., \& Witt, P. A. (1994). Change and stability in leisure constraints: A comparison of two surveys.

Karasar, N. (2000). Bilimsel Arastırma Yöntemi, 10. Baskı, Ankara, Nobel Yayın Dağıtım.

Kenar, İ. (2012). Teknoloji ve Derslerde Teknoloji Kullanımına Yönelik Veli Tutum Ölçeği Geliştirilmesi ve Tablet PC Uygulaması. Eğitim Bilimleri Araştırma Dergisi, 2(2), 123-139.

Kindal, A., Shores, T. W., \& Stephanie, T. W. (2010). Pursuing Leisure During Leisure-Time Physical Activity. Journal of Physical Activity and Health, 7, 685-694. https://doi.org/10.1123/jpah.7.5.685

Öner, N. (1997). Türkiye'de Kullanılan Psikolojik Testler bir Basvuru Kaynağı. 3.Baskı, Đstanbul, Boğaziçi Üniversitesi Matbaası.

Özdamar, K. (2002). Paket Programlar ile Đstatistik Veri Analizi, 4. Bask1, Eskisehir, Kaan Kitapevi, 661-673.

Raymore, L., Godbey, G., Crawford, D., \& von Eye, A. (1993). Nature and process of leisure constraints: An empirical test. Leisure Sciences, 15(2), 99-113. https://doi.org/10.1080/01490409309513191

Reeder, C. W, \& Linkowski, D. C. (1976). An institute on attitudinal, legal, and leisure barriers to the disabled. Rehabilitation Counseling Bulletin, 20, 76-79.

Samdahl, D. M., \& Jekubovich, N. J. (1997). A critique of leisure constraints: Comparative analyses and $\begin{array}{lllll}\text { understandings. Journal of Leisure } & \text { Research, }\end{array}$ https://doi.org/10.1080/00222216.1997.11949807 
Sindik, J., \& Puljic, V. (2010). Attitudes Towards Leisure Time Motivation at Players in Sokaz Table Tenis Recreational Leagues. Acta Kinesiologica, 4(1), 49-53.

Tezbaşaran, A. (1997). Likert Tipi Ölçek Gelistirme Kılavuzu, 2. Baskı, Ankara, Türk Psikologlar Derneği Yayınları.

Ting-Wen, W., \& Chung-Tai W. (2016). Identifying Leisure Constraints Among College Students - Application of a Fuzzy Approach. International Journal of Organizational Innovation, 8(4), 177-187.

Tütüncü, Ö., Aydın, İ., Küçükusta, D., Avcı, N., \& Taş, İ. (2011). Üniversite Öğrencilerinin Rekreasyon Faaliyetlerine Katılımını Etkileyen Unsurların Analizi. Spor Bilimleri Dergisi, 22(2), 69-83.

Walker, G., \& Virden, R. (2005). Constraints on outdoor recreation. In E. L. Jackson (Ed.), Constraints to Leisure (pp. 201-219). State College, PA: Venture.

Witt, P., \& Goodale, T. (1981). The relationship between barriers to leisure enjoyment and family stages. Leisure Sciences, 4, 29-49. https://doi.org/10.1080/01490408109512948

\section{Appendix A}

\section{Turkish Version of the Leisure Constraints Questionnaire}

\begin{tabular}{|c|c|}
\hline Questions & \\
\hline 1- Yorgun Hissettiriyor & $\begin{array}{l}\text { 16- Aktiviteler için programlanan zaman çizelgesi bana uygun } \\
\text { değil }\end{array}$ \\
\hline 2- Sakatlık yaşamaktan korkuyorum & 17- Ulaşım çok zamanımı alıyor \\
\hline 3- Sosyal durumumdan memnun değilim & 18- Evime yakın aktivitelere katılabileceğim yer yok \\
\hline $\begin{array}{l}\text { 4- Rekreasyonel fiziksel aktivitelere katılmak yorgun } \\
\text { hissettiriyor }\end{array}$ & 19- Arabam yok \\
\hline 5- Sağlık problemlerim var & 20- Masrafları karşılayamıyorum \\
\hline 6- Kendime güvenmiyorum & 21- Geçmiş deneyimlerimde aktivitelerden çok keyif almadım \\
\hline 7- Aktiviteler için yeterince fit değilim & $\begin{array}{l}\text { 22- Aktivitelerin düzenli yaşam tarzıma etki etmesini } \\
\text { istemiyorum }\end{array}$ \\
\hline 8- Aktivitelere nerede katılacağımı bilmiyorum & 23- İlgimi çekmiyor \\
\hline 9- Bu tür aktiviteleri bana öğretebilecek eğitmen yok & $\begin{array}{l}\text { 24- Arkadaşlarımla katılmak istiyorum ancak onların böyle bir } \\
\text { zamanı yok }\end{array}$ \\
\hline 10- Bu tür aktiviteleri nerede öğreneceğimi bilmiyorum & 25- Beraber aktivitelere katılacak kimse yok \\
\hline 11- Aktiviteler için yetenekli değilim & 26- Arkadaşlarım aktivitelere katılmak istemiyor \\
\hline 12- Bu tür aktiviteler için tesisler çok kötü & 27- Aileme çok zaman ayırdığım için aktivitelere katılamıyorum \\
\hline 13- Tesisler çok kalabalık & 28- Çok fazla çalıştığım için aktivitelere katılamıyorum \\
\hline 14- Aktiviteler için var olan tesisler yetersiz & $\begin{array}{lrrr}29- & \text { Sosyal } & \text { sorumluluklarımdan } & \text { dolayı } \\
\text { katılamıyorum } & & & \\
\end{array}$ \\
\hline & \\
\hline
\end{tabular}

\section{Copyrights}

Copyright for this article is retained by the author, with first publication rights granted to the journal.

This is an open-access article distributed under the terms and conditions of the Creative Commons Attribution license (http://creativecommons.org/licenses/by/4.0/). 